\title{
Underreporting of energy intake is less common among pregnant women in Indonesia
}

\author{
Anna Winkvist ${ }^{1, *}$, Viveka Persson ${ }^{1,2}$ and T Ninuk S Hartini ${ }^{1,3,4}$ \\ ${ }^{1}$ Epidemiology, Department of Public Health and Clinical Medicine, Umeå University, SE-901 85 Umeå, Sweden: \\ ${ }^{2}$ Section for International Maternal and Child Health, Department of Women's and Children's Health, Uppsala \\ University, Sweden: ${ }^{3}$ Nutrition Academy, Ministry of Health, Yogyakarta, Indonesia: ${ }^{4}$ Community Health and \\ Nutrition Research Laboratory, Faculty of Medicine, University of Gadjah Mada, Yogyakarta, Indonesia
}

Submitted 18 June 2001: Accepted 26 October 2001

\begin{abstract}
Objectives: To evaluate the ratio of reported energy intake to basal metabolic rate (EI/BMR) among pregnant Indonesian women, as well as identifying risk factors for being an underreporter.

Design: Longitudinal study of dietary intake, using six repeated 24-hour diet recalls each trimester. Basal metabolic rate was estimated from body weight and physical activity from occupation. The lower 95\% confidence interval for plausible EI/BMR was calculated and the proportion of underreporters estimated. Risk factors for being an underreporter were assessed in multivariate logistic regression analyses.

Setting: Purworejo District, central Java, Indonesia.

Subjects: Pregnant women $(n=490)$.

Results: For the three trimesters, EI/BMR ratio was $1.33 \pm 0.48,1.53 \pm 0.43$ and $1.52 \pm$ 0.40 (mean \pm standard deviation), respectively. The proportion of underreporters was $29.7 \%, 16.2 \%$ and $17.6 \%$. Characteristics significantly associated with underreporting in at least one trimester included high body mass index and low education. Conclusions: Levels of underreporting were low among the pregnant Indonesian women during the second and third trimesters. The low EI/BMR ratio during the first trimester likely reflects a true low intake due to nausea, rather than underreporting. Risk factors for being an underreporter included those known from developed countries, i.e. obesity and low education.
\end{abstract}

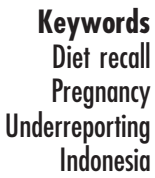

Keywords Diet recall ndonesia
In the last two decades, many researchers have demonstrated that reported dietary intake data seriously underestimate the true habitual intake when compared with the doubly labelled water method and the 24-hour urinary nitrogen excretion method ${ }^{1-4}$. The underreporting is systematic, with higher levels of underreporting among obese subjects as well as among people of low income, and more commonly for energy than for protein ${ }^{5-8}$.

Unfortunately, large epidemiological studies often have to rely on reported dietary intake methods. However, Goldberg and colleagues ${ }^{9}$ have suggested that studies of energy intake be evaluated by comparing the ratio of reported energy intake to basal metabolic rate (EI/BMR) with physiologically plausible ratios of total energy expenditure to basal metabolic rate (TEE/BMR). The latter ratio is also referred to as the physical activity level (PAL). Too low ratios are obviously incompatible with weight maintenance even at minimal physical activity. For sedentary people, PAL has been estimated to be $1.55^{10}$. Furthermore, doubly labelled water studies of energy expenditure among non-ambulant subjects and elite endurance athletes suggest a physiological range of PAL of $1.2-4.5^{11}$

Goldberg and co-workers have offered formulas to calculate the lower confidence limits of agreement between reported EI/BMR and PAL, for groups as well as for individuals ${ }^{7,9}$. Individuals with a ratio below the lower limit are regarded as underreporters. The formulas take into account the within-subject day-to-day variation in energy intake, the number of days of dietary intake assessment, the precision of estimated versus measured BMR, the between-subject variability in PAL, and the expected PAL of the subjects. The method has been found to have high specificity (proportion of non-underreporters correctly identified: close to 1) but lower sensitivity (proportion of underreporters correctly identified: about $0.5)$; the latter may be improved by the inclusion of information on physical activity ${ }^{12}$. Of course, underreporting may occur at all levels of EI/BMR. However, validation studies using urinary nitrogen or doubly labelled water suggest that underreporting bias is more common at the lower end of energy intake ${ }^{13}$. 
Since the appearance of these formulas, multiple studies have reported on the ratio of EI/BMR. In a summary of 37 studies from the Western world, the overall mean ratio was 1.43 with a range of $0.99-1.88^{3}$. More recent studies in Europe and the USA have found ratios between 1.22 and $1.74^{14-18}$. The proportion of underreporters ranged from $12 \%$ to $46 \%$ for these studies, and a review of large national dietary surveys found the same proportion to be 18$54 \%{ }^{19}$. The different results in these studies may partially be explained by the different dietary assessment techniques used as well as different criteria used for identifying underreporters.

Only one study has reported on this ratio for a population in a developing country ${ }^{20}$. Here, EI/BMR equalled 1.56 among Egyptian women, in contrast to 1.13 among American women studied with similar techniques. Furthermore, the proportion of underreporters was only $10 \%$ among the Egyptian women but 35\% among the American women. These findings suggest that assumptions about underreporting derived from populations in industrialised countries may need to be validated also in populations in developing countries. We have recently reported that variance component ratios for macronutrients were generally lower for pregnant Indonesian women than those reported for pregnant women in the industrialised world ${ }^{21}$. More methodological research is obviously needed in developing countries, so that future dietary studies can be planned with equal precision to those in the industrialised world.

Many studies of dietary intake in industrialised and developing countries are performed on pregnant women. Validation of these studies also is urgently needed. However, the formulas developed by Goldberg et al. ${ }^{9}$ assume energy balance, i.e. that energy intake equals energy expenditure and that weight is stable. Are they applicable also to pregnant women, who are expected to gain weight? It is recommended that pregnant women have an increased energy intake of $840-1250 \mathrm{~kJ} \mathrm{day}^{-1}$ to cover the costs of synthesising the product of conception and the fat deposition, as well as the increased $\mathrm{BMR}^{22}$. The increase in BMR has been estimated to correspond to 187 , 414,619 and $950 \mathrm{~kJ} \mathrm{day}^{-1}$ for weeks $0-10,10-20,20-30$ and $30-40^{23}$, although a wide variability has since been found with the doubly labelled water method ${ }^{24}$. Hence, the ratio of energy intake to estimated basal metabolic rate $\left(\mathrm{EI} / \mathrm{BMR}_{\mathrm{est}}\right.$ ) in early pregnancy is likely higher than before pregnancy, because the increase in the numerator due to increased dietary intake is larger than the increase in the denominator due to increased BMR. Rather than 1.55 (for a dietary intake of $7500 \mathrm{~kJ}$ and BMR of $4850 \mathrm{~kJ}$ for a nonpregnant woman), the ratio may be 1.65 . Using the same example, during the second trimester the ratio may be 1.60 , and during the third trimester the ratio may again be 1.55 because here the increase in dietary intake is matched by a similar increase in BMR. Consequently, cut-off values for identifying underreporters during pregnancy in affluent societies should perhaps be adjusted slightly upwards during the first and second trimesters.

Furthermore, the wide variability in BMR in response to pregnancy is also of concern for the applicability of Goldberg et al.'s' formula to pregnant women. In developing countries, many studies have found adaptations to low dietary intake and poor nutritional status among pregnant women that include reductions in BMR below non-pregnant levels during early pregnancy, followed by an increase during later pregnancy ${ }^{24}$. Hence, energy status at conception influences changes in BMR during pregnancy. Even so, among women of similar initial energy status in both affluent and poor societies, variations in BMR during pregnancy are large. However, in affluent societies (e.g. Sweden, England, Scotland and the Netherlands), the average BMR level for groups of pregnant women shows a steady increase during pregnancy. For many poorer societies (e.g. the Gambia), average levels exhibit a non-linear pattern with an initial decrease followed by an increase. Studies of pregnant women in emerging economies, e.g. the Philippines and Thailand, have revealed patterns of BMR closer to those of women in affluent societies - i.e. an increase in BMR throughout pregnancy ${ }^{24}$. Likely, Indonesian women resemble those of the Philippines and Thailand, with minor increases in BMR during early pregnancy and larger increases during later pregnancy. Total weight gain during pregnancy for a sub-sample of the Indonesian women studied in this paper, who delivered singleton live infants and for whom information on pre-pregnant weight existed $(n=251)$, equalled $8.3 \pm$ $3.6 \mathrm{~kg}$ with gains during each trimester of $0.08 \pm 0.26$, $0.34 \pm 0.23$ and $0.26 \pm 0.21 \mathrm{kgweek}^{-1}$, respectively ${ }^{25}$. These values are almost identical to those found in a study of pregnant women in the Philippines ${ }^{26}$, indicating similar energy balances of the two populations.

In sum, we believe that it is possible to evaluate reported dietary intake of Indonesian women against estimated PAL, assuming that the early pregnant EI/BMR may be slightly higher than that of non-pregnant Indonesian women because of higher food intake concurrent with somewhat higher BMR. Furthermore, a decrease in BMR in early pregnancy is assumed not to be common.

We here report on EI/BMR ratios among pregnant Indonesian women, whose dietary intake was studied during each trimester with six repeated 24-hour recalls. We also describe risk factors for being an underreporter among the women.

\section{Subjects and methods}

\section{Study site and sampling design}

The study was conducted in Purworejo District, Central Java, Indonesia. The total population in 1996 was 756906. Since 1994, the Community Health and Nutrition Research 
Laboratory (CHN-RL) of Gadjah Mada University, Yogyakarta, and the Indonesian Ministry of Health have been operating a surveillance system in the district. A two-stage cluster sampling method was used to select a 10\% sample of households representative of the district ${ }^{27}$. From 1994 to 1998, each household was visited every third month for data collection. In addition, to identify new pregnancies, households with women likely to become pregnant (i.e. married women of reproductive age) were visited monthly. The nutritional status of women of reproductive age in the area is described in detail elsewhere ${ }^{28,29}$.

Between April 1996 and October 1998, a cohort of 846 women in early pregnancy was recruited for a study on nutritional status during reproduction. Within this framework, dietary data were collected among a sub-sample of 490 women. The remaining 356 women were not included, mainly because they were recruited before dietary assessments were started but also because of refusals, migration or abortions, stillbirths or death. Among the 490 women who form the study sample for the present analyses, 152 women had dietary information for the first trimester, 448 women for the second trimester and 419 women for the third trimester. Only 123 women had information in all three trimesters. Weight was measured monthly but coverage was not complete. In the analyses below, weights at 2, 5 and 8 months of pregnancy have been used. When these measures were missing, weights from the month immediately preceding or following the missing ones were used. Thus, the total sample of women with both body weight and dietary information was 148, 445 and 414 for the three trimesters, respectively.

\section{Dietary intake assessment}

To estimate dietary intake, six 24-hour recalls were performed in each trimester, randomly distributed among the five different days of the Javanese calendar on nonconsecutive days. The interviews were performed by 22 trained female interviewers and each respondent was interviewed at home by the same interviewer for all measurements. Detailed descriptions of all foods, beverages, and vitamin and mineral supplements consumed between 00.00 a.m. and midnight the previous day, as well as cooking methods, were recorded. Quantities were estimated using seven household utensils and approximately 20 types of food model. The average weight of each type of food equivalent to the portion sizes and fitting into the household utensils were estimated to the nearest gram. Few standard food recipes are used in Central Java; therefore over 11000 local recipes for mixed dishes were collected during the study. Some of these dishes were prepared in a test kitchen.

Data-form editing was conducted in the field within a few days and supervisors checked all interviewers periodically. A random sample of $5 \%$ of interviews was repeated later the same day for quality control. To calculate nutrient intakes, a computer program (Inafood) was developed, which mainly uses the Indonesian nutrient composition database $\mathrm{e}^{30-32}$. For energy values, 92\% came from these sources. Food items where nutrient content was lacking were sent to the Research and Development Centre for Nutrition, Bogor, Indonesia, for biochemical analysis. To validate the Inafood program, total dietary intake was calculated manually from the nutrient composition tables for four dietary recalls by students at the Nutrition Academy, Yogyakarta. For energy, complete agreement was obtained. For protein, fat and carbohydrates, differences (expressed as percentage of computed total) were in the ranges of $1-15 \%, 0-5 \%$ and $0-3 \%$, respectively. Ethical approval was received from the research ethics committees of the medical faculties of Gadjah Mada University, Yogyakarta, Indonesia, and Umeå University, Umeå, Sweden.

\section{Derivation of cut-off limits for $\mathrm{EI} / \mathrm{BMR}$}

The cut-off limits for physiologically plausible energy intakes at weight maintenance were calculated as described by Goldberg et al. ${ }^{9}$ :

$$
\mathrm{EI} / \mathrm{BMR}>\mathrm{TEE} / \mathrm{BMR} \times \exp [\mathrm{SD} \times(S / 100) / \sqrt{n}],
$$

where $\mathrm{SD}$ is the number of standard deviations corresponding to the confidence interval chosen, $S$ is the overall coefficient of variation for PAL taking into account the variability in EI and BMR, and $n$ is the number of subjects included. $S$ is calculated as follows:

$$
S=\sqrt{\left(\mathrm{CW}_{\mathrm{IW}}^{2}+\mathrm{CV}_{\mathrm{B}}^{2}+\mathrm{CV}_{\mathrm{P}}^{2}\right)}
$$

where $\mathrm{CW}_{\mathrm{IW}}^{2}$ is the within-individual variation in energy intake, $k$ is the number of days of diet assessment, $\mathrm{CV}_{\mathrm{B}}^{2}$ is the precision of estimated vs. measured BMR, and $\mathrm{CV}_{\mathrm{P}}^{2}$ is the between-subject variation in PAL. For our study, SD was set to -2 to obtain the lower limit of a $95 \%$ confidence interval (CI). Further, $n$ equalled 1 individual, $k$ equalled 6 days of repeated recall, $\mathrm{CV}_{\mathrm{B}}^{2}$ was taken as $8 \%{ }^{33}$ and $\mathrm{CV}_{\mathrm{P}}^{2}$ was assumed to be $12.5 \%^{10}$. Furthermore, $\mathrm{CW}_{\text {IW }}^{2}$ was derived from our own data ${ }^{21}$ and corresponded to $26 \%$, $22 \%$ and $20 \%$ for the three trimesters of pregnancy, respectively. Finally, TEE/BMR was chosen as 1.55 for the sample as a whole ${ }^{10}$. However, analyses also were performed with women classified into two categories of physical activity based on occupation (none of the women regularly participated in any sports activities). Women working as professionals, managers, clerks, saleswomen, providers of service, housewives or if unemployed were classified into light physical activity and the value for TEE/BMR of 1.55 was applied. Women working as farmers or labourers were classified into moderate physical activity and the value for TEE/BMR of 1.64 was instead used ${ }^{10}$.

For the first trimester, the lower $95 \%$ CI limit of EI/BMR equalled $1.55 \times 0.70=1.08$ or $1.64 \times 0.70=1.14$. For the second trimester, the limit was $1.55 \times 0.71=1.10$ or $1.64 \times$ 
$0.71=1.16$. Finally, for the third trimester, the limit was $1.55 \times 0.71=1.11$ or $1.64 \times 0.71=1.17$. BMR was estimated from body weight in each trimester using the formula ${ }^{10}: \mathrm{BMR}=(0.0615 \times$ body weight $)+2.08$. Underreporters were defined as those women falling below our calculated lower $95 \%$ CI for $\mathrm{EI} / \mathrm{BMR}_{\mathrm{est}}$ for each trimester.

\section{Statistical methods}

Data were analysed with the SPSS/PC statistical software (version 9.0). Caloric intake in each trimester was normally distributed. Differences in background characteristics between groups of women were compared using Student's $t$-test and $\chi^{2}$ tests. Bivariate and multivariate logistic regression analyses were performed to evaluate characteristics associated with being an underreporter. Values are reported as mean \pm standard deviation (SD).

\section{Results}

\section{Sample characteristics}

The age of the study sample of 490 women was $28.8 \pm 5.4$ years and the mean parity was $1.6 \pm 1.4$. The mean height and mid-upper arm circumference (MUAC) at two months of pregnancy were $150.0 \pm 4.9 \mathrm{~cm}$ and $25.3 \pm 2.9 \mathrm{~cm}$, respectively. Pre-pregnant weight for a sub-sample of 275 women was $47.7 \pm 8.0 \mathrm{~kg}$ and pre-pregnant BMI was $21.2 \pm 3.1 \mathrm{~kg} \mathrm{~m}^{-2}$. At 2 months of pregnancy, BMI of 471 women with complete data was $22.0 \pm 4.0 \mathrm{~kg} \mathrm{~m}^{-2}$. Weight gain during pregnancy has been presented elsewhere (see above $)^{25}$. Over 90\% lived in the rural areas and $44 \%$ had seven years of schooling or more. In total, $59 \%$ of the women were classified into light physical activity and 41\% were classified into moderate physical activity.

\section{Representativeness of the study sample}

The sample of 490 women from the pregnancy cohort included in the dietary intake analyses did not differ significantly from those excluded $(n=356)$ with respect to age, parity, height, MUAC at 2 months of pregnancy, altitude of residence, education, type of toilet or water source $(P>0.05)$. However, a greater proportion of those

Table 1 Reported energy intake and energy intake/basal metabolic rate $\left(\mathrm{El}_{\mathrm{BMR}} \mathrm{BM}\right)$ ratio for the pregnant Indonesian women

\begin{tabular}{|c|c|c|c|}
\hline & $n$ & $\begin{array}{l}\text { Reported } \\
\text { intake } \\
\left(\mathrm{MJ} \mathrm{day}^{-1}\right)\end{array}$ & $\mathrm{El} / \mathrm{BMR}_{\mathrm{est}}$ \\
\hline First trimester & 148 & $6.68 \pm 2.34$ & $1.33^{\star} \pm 0.48$ \\
\hline Second trimester & 445 & $7.91 \pm 2.13$ & $1.53 \dagger \pm 0.43$ \\
\hline Third trimester & 414 & $8.19 \pm 2.05$ & $1.52 \ddagger \pm 0.40$ \\
\hline
\end{tabular}

* Based on body weight at 2 months of pregnancy. Calculations using prepregnant weight or weight at 1 or 3 months of pregnancy yielded ratios of $1.32,1.26$ and 1.33

† Based on body weight at 5 months of pregnancy. Calculations using weight at 4 or 6 months of pregnancy yielded ratios of 1.57 and 1.51 .

¥Based on body weight at 8 months of pregnancy. Calculations using weight at 7 or 9 months of pregnancy yielded ratios of 1.54 and 1.53 .
Table 2 Proportion of Indonesian women with energy intake/basal metabolic rate $\left(\mathrm{El}^{\mathrm{B}} \mathrm{BMR}_{\mathrm{est}}\right)$ ratio below calculated lower $95 \%$ confidence limits during the three trimesters, according to level of physical activity*

\begin{tabular}{|c|c|c|c|c|c|c|}
\hline & \multicolumn{3}{|c|}{$\begin{array}{l}\text { Light physical } \\
\text { activity }\end{array}$} & \multicolumn{3}{|c|}{$\begin{array}{c}\text { Moderate physical } \\
\text { activity }\end{array}$} \\
\hline & $n$ & $\begin{array}{l}\text { Lower } \\
\text { cut-off }\end{array}$ & $\%$ below & $n$ & $\begin{array}{l}\text { Lower } \\
\text { cut-off }\end{array}$ & $\%$ below \\
\hline First trimest & 85 & 1.08 & 29.4 & 63 & 1.14 & 30.2 \\
\hline Second trimester & 268 & 1.10 & 13.1 & 177 & 1.16 & 20.9 \\
\hline Third trimester & 247 & 1.11 & 14.2 & 167 & 1.17 & 22.8 \\
\hline
\end{tabular}

* Level of physical activity estimated from occupation.

included in the analyses lived in urban areas (10\% vs. $4.5 \%, P<0.01$ ), and fewer worked in agriculture (38\% vs. 47\%, $P<0.05)$.

The mean height and age of the total sample of women of reproductive age $(n=13094)$ in Purworejo was $149.1 \pm 5.1 \mathrm{~cm}$ and $30.4 \pm 9.7$ years, respectively, both different from the study sample $(P<0.05)$. Forty-six per cent of these women had seven years of schooling or more and 14\% worked in agriculture, both no different from the study sample. However, a greater proportion, 14\% compared with $10 \%$, lived in urban areas $(P<0.01)^{26}$.

\section{Ratio of energy intake to estimated basal metabolic rate}

Mean reported energy intake as well as mean EI/BMR est ratio are shown for all three trimesters in Table 1 . During the three trimesters, mean intake was $6680 \pm 2337,7909 \pm$ 2128 and $8193 \pm 2048 \mathrm{~kJ}$, respectively. The proportion of underreporters in each trimester was 29.7, 13.7 and 15.0\%, respectively, when all women were classified as sedentary.

When level of physical activity as estimated from occupation was taken into account, the proportion of underreporters increased (Table 2). In total, the proportion of underreporters for the whole sample now equalled 29.7, 16.2 and $17.6 \%$ for the trimesters, respectively.

\section{Identifying women who underreported}

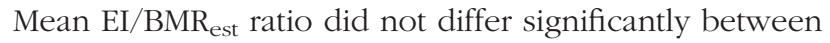
urban and rural women. For urban women, the ratio was $1.31 \pm 0.67,1.56 \pm 0.53$ and $1.51 \pm 0.50$ for the three trimesters, respectively. For rural women, the ratio was $1.33 \pm 0.46,1.53 \pm 0.42$ and $1.52 \pm 0.38$, respectively. Various anthropometric and sociodemographic factors were evaluated simultaneously as risk factors for becoming an underreporter (e.g. body mass index, height, age, parity, education and socio-economic variables). The characteristics that exhibited a significant association with risk of becoming an underreporter in any trimester in bivariate analyses were included in the multivariate models. In the multivariate analysis, high body mass index was associated with a significantly higher risk of being an underreporter (Table 3). Low education 
Table 3 Anthropometric and sociodemographic factors associated with underreporting*, expressed as multivariate odds ratio (MOR) and 95\% confidence interval (Cl)

\begin{tabular}{|c|c|c|c|c|c|c|}
\hline & \multicolumn{2}{|c|}{ First trimester } & \multicolumn{2}{|c|}{ Second trimester } & \multicolumn{2}{|c|}{ Third trimester } \\
\hline & MOR† & $95 \% \mathrm{Cl}$ & MOR & $95 \% \mathrm{Cl}$ & MOR & $95 \% \mathrm{Cl}$ \\
\hline \multicolumn{7}{|c|}{ Body mass index $\ddagger\left(\mathrm{kg} \mathrm{m}^{-2}\right)$} \\
\hline$\leq 19.00$ & 1.00 & & 1.00 & & 1.00 & \\
\hline $19.01-25.00$ & 2.02 & $0.63-6.45$ & 1.00 & $0.41-2.50$ & 1.67 & $0.61-45.49$ \\
\hline$>25.00$ & 6.76 & $1.51-30.22$ & 3.62 & $1.07-12.77$ & 8.17 & $2.32-28.73$ \\
\hline \multicolumn{7}{|l|}{ Education (years) } \\
\hline$\geq 10$ & 1.00 & & 1.00 & & 1.00 & \\
\hline $7-9$ & 1.28 & $0.36-4.53$ & 1.82 & $1.10-27.79$ & 1.46 & $0.46-4.64$ \\
\hline $0-6$ & 2.04 & $0.63-6.55$ & 2.19 & $1.63-36.01$ & 1.82 & $0.66-5.09$ \\
\hline \multicolumn{7}{|l|}{ Altitude } \\
\hline Coastal & 1.00 & & 1.00 & & 1.00 & \\
\hline Lowland & 1.68 & $0.53-5.25$ & 1.81 & $0.75-4.36$ & 1.44 & $0.58-3.61$ \\
\hline Hilly/mountain & 1.31 & $0.40-4.24$ & 0.79 & $0.25-2.66$ & 2.79 & $0.86-9.00$ \\
\hline
\end{tabular}

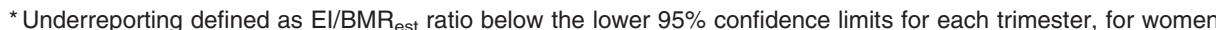
classified as having light and moderate physical activity, respectively.

† Multivariate models with all three explanatory variables included.

$\ddagger$ Body mass index calculated from weight at 2 months of pregnancy.

remained a significant risk factor in the second trimester, whereas altitude became non-significant in all three trimesters. Women of higher parity tended to have higher risk of being underreporters in all three trimesters, but this was not significant even on bivariate level.

\section{Discussion}

During the second and third trimesters, mean EI/BMR ratio among the pregnant Indonesian women was 1.53 and 1.52 , respectively. Both values are close to the TEE/BMR value assumed for populations with light physical activity (1.55), indicating low levels of underreporting. Also, the proportion of women classified as underreporters was only $16.2 \%$ and $17.6 \%$, when physical activity was taken into account. These levels are lower than those reported among many women in Western countries, ranging between 12 and $46 \%{ }^{14-18}$. Similarly, low rates of underreporting among women from a developing country were recently reported by Harrison and colleagues ${ }^{20}$, who found $10 \%$ of underreporters among Egyptian women compared with 35\% among American women studied with similar methodology.

Several previous studies from Indonesia have reported the dietary intake among pregnant women to be $6300 \mathrm{~kJ}^{34,35}$. However, assuming the same body size as Central Java women, this equals an EI/BMR est ratio of 1.2 , which is the lower value of the physiological range ${ }^{11}$. Hence, we do not believe that our higher values represent an overestimation.

During the first trimester, the Central Java women exhibited a mean $\mathrm{EI} / \mathrm{BMR}_{\mathrm{est}}$ ratio of 1.33 . The proportion of underreporters was estimated to be $29.7 \%$. However, we believe that this lower ratio mainly reflects an inadequate dietary intake and not underreporting. During the fieldwork, all women reporting a dietary intake below $4200 \mathrm{~kJ}$ were revisited and interviewed about reasons for the low intake. Many women reported nausea during the first trimester and weight gains during that period only corresponded to $0.08 \pm 0.26 \mathrm{~kg}$ per week ${ }^{25}$.

Because pregnant women have an increased dietary intake and a somewhat increased BMR, likely leading overall to a slightly higher EI/BMR, the cut-off points used should perhaps have been adjusted upwards in the first and second trimesters (see above). Even so, the proportion of underreporters would be low among the Indonesian women.

As discussed above, use of Goldberg et al.'s 9 formula without inclusion of information on physical activity, to better estimate PAL, leads to poor sensitivity (about 0.5 ) in correctly identifying underreporters. We did not have access to information on physical activity but instead included information on occupation. The majority of the Indonesian women were rural, and the Western lifestyle of leisure physical activity is not common. Therefore, we believe that occupation is a useful proxy for physical activity in this population. Hence, the sensitivity of our analysis should be higher than 0.5 .

Multiple studies have found low EI/BMR ratio to be associated with several factors linked to poor health. The only significant risk factors for being an underreporter among the Indonesian women were high body mass index and low education. These risk factors have also been found in studies in the Western world ${ }^{15,16,18}$. However, among Egyptian women, no relationship was found with formal education and only a weak association was found with body mass index ${ }^{20}$. Among the Indonesian women, no associations were found between height, age or indicators of socio-economic status and risk of being an underreporter. In contrast, these variables have been related to risk of underreporting in many of the studies from the Western world ${ }^{15,16,18}$.

Women included in the analysis did not differ from those excluded on most background characteristics, 
except for area of residence and occupation. Neither of these variables was related to risk of being an underreporter. In comparison with the surveillance sample of 13094 women of reproductive age in the district, women included in the analysis only differed with respect to area of residence, age and height. Neither of the former two was related to risk of being an underreporter. Larger body mass index, of which height is a component, was related to a higher risk of being an underreporter. Women included were only $0.9 \mathrm{~cm}$ taller than women in the surveillance sample; however, due to the large size of the surveillance sample, small differences between the two samples become significant. In sum, we believe that the patterns of underreporting found among the 490 women are representative for pregnant women in Purworejo District.

In summary, Indonesian women had levels of underreporting at the lower end of those found for women from the Western world. However, several risk factors for underreporting (high body mass index, low education) that have been found in the Western world also appeared among the Indonesian women. Our results underscore the need for more methodological research in developing countries.

\section{Acknowledgements}

This research was funded by grants from Sida/SAREC (Swedish International Development Cooperation Agency, Department of Research Cooperation) and the World Bank through the Community Health and Nutrition Development Project of the Ministry of Health, Indonesia (IBRD Loan No. 3550-IND). Data analysis and preparation of the manuscript were facilitated by support from STINT (Swedish Foundation for International Cooperation in Research and Higher Education).

\section{References}

1 Prentice AM, Black AE, Coward WA, Davies H, Goldberg GR, Murgatroyd P, Ashford J, Sawyer M, Whitehead RG. High levels of energy expenditure in obese women. $\mathrm{Br}$. Med. J. 1986; 292: 983-7.

2 Schoeller DA, Bandini LG, Dietz WH. Inaccuracies in selfreported intake identified by comparison with the doublylabelled water method. Can. J. Physiol. Pharmacol. 1990; 68: 941-9.

3 Black AE, Goldberg GR, Jebb SA, Livingstone MBE, Cole TJ, Prentice AM. Critical evaluation of energy intake data using fundamental principles of energy physiology: 2. Evaluating the results of published surveys. Eur. J. Clin. Nutr. 1991; 45: 583-99.

4 Black AE, Jebb SA, Bingham SA. Validation of energy and protein intake assessed by diet history and weighed records against energy expenditure and 24-hour urinary nitrogen excretion. Proc. Nutr. Soc. 1991; 50: 108A.

5 Heitmann BL. The influence of fatness, weight change, slimming history and other lifestyle variables on diet reporting in Danish men and women aged 35-65 years. Int. J. Obes. 1993; 17: 329-36.
6 Livingstone MBE, Prentice AM, Strain JJ, Coward WA, Black AE, Barker ME, McKenna PG, Whitehead RG. Accuracy of weighed dietary records in studies of diet and health. $B r$. Med.J. 1990; 300: 708-12.

7 Goldberg GR, Black AE. Assessment of the validity of reported energy intakes - a review and recent developments. Scand. J. Nutr. 1998; 42: 6-9.

8 Heitmann BL, Lissner L. Dietary underreporting by obese individuals - is it specific or non-specific? Br. Med.J. 1995; 311: 986-9.

9 Goldberg GR, Black AE, Jebb SA, Cole TJ, Murgatroyed PR, Coward WA, Prentice AM. Critical evaluation of energy intake data using fundamental principles of energy physiology: 1. Derivation of cut-off limits to identify underrecording. Eur. J. Clin. Nutr. 1991; 45: 569-81.

$10 \mathrm{FAO} / \mathrm{WHO} / \mathrm{UNU}$. Energy and Protein Requirements. WHO Technical Report Series No. 724. Geneva: World Health Organization (WHO), 1985.

11 Black AE, Coward WA, Cole TJ, Prentice AM. Human energy expenditure in affluent societies: an analysis of 574 doublylabelled water measurements. Eur. J. Clin. Nutr. 1996; 50: 72-92.

12 Black AE. The sensitivity and specificity of the Goldberg cutoff for EI:BMR for identifying diet reports of poor validity. Eur. J. Clin. Nutr. 2000; 54: 395-404.

13 Black AE, Prentice AM, Goldberg GR, Jebb SA, Bingham SA, Livingstone MBE, Coward WA. Measurements of total energy expenditure provide insights into the validity of dietary measurements of energy intake. J. Am. Diet. Assoc. 1993; 93: $572-9$.

14 Haraldsdottir J, Sandström B. Detection of underestimated energy intake in young adults. Int. J. Epidemiol. 1994; 23(3): $577-82$.

15 Price GM, Paul AA, Cole TJ, Wadsworth MEJ. Characteristics of the low-energy reporters in a longitudinal national dietary survey. Br. J. Nutr. 1997; 77: 833-51.

16 Pryer JA, Vrijheid M, Nichols R, Kiggins M, Elliott P. Who are the low energy reporters in the Dietary and Nutritional Survey of British adults? Int. J. Epidemiol. 1997; 26: 146-54.

17 Briefel RR, Sempos CT, McDowell MA, Chien S, Alaimo K. Dietary methods research in the third National Health and Nutrition Examination Survey: underreporting of energy intake. Am.J. Clin. Nutr. 1997; 65(Suppl.): 1203S-9S.

18 Gnardellis C, Boulou C, Trichopoulou A. Magnitude, determinants and impact of under-reporting of energy intake in a cohort study in Greece. Public Health Nutr. 1998; 1(2): $131-7$.

19 Macdiarmid J, Blundell J. Assessing dietary intake: who, what and why of under-reporting. Nutr. Res. Rev. 1998; 11: $231-53$.

20 Harrison GG, Galal OM, Ibrahim N, Khorshid A, Stormer A, Leslie J, Saleh NT. Underreporting of food intake by dietary recall is not universal: a comparison of data from Egyptian and American women. J. Nutr. 2000; 130: 2049-54.

21 Persson V, Winkvist A, Hartini TNS, Greiner T, Hakimi M, Stenlund H. Variability in nutrient intake in pregnant women in Indonesia. J. Nutr. 2001; 131: 325-30.

22 National Research Council. Recommended Dietary Allowances, 10th ed. Report of the Subcommittee on the Tenth Edition of the RDAs, Food and Nutrition Board, Commission on Life Sciences. Washington, DC: National Academy Press, 1989.

23 Hytten FE. Nutrition. In: Hytten FE, Chamberlain G, eds. Clinical Physiology in Obstetrics. Oxford: Blackwell Scientific Publications, 1980; 163-92.

24 Prentice AM, Poppitt SD, Goldberg GR, Murgatroyd PR, Black AE, Coward WA. Energy balance in pregnancy and lactation. In: Allen L, King J, Lönnerdal B, eds. Nutrient Regulation During Pregnancy, Lactation and Infant Growth. New York: Plenum Press, 1994. 
25 Winkvist A, Stenlund H, Hakimi M, Nurdiati DS, Dibley MJ. Weight gain patterns from pre-pregnancy until delivery among women in Central Java, Indonesia. Am. J. Clin. Nutr 2002 [in press].

26 Siega-Riz AM, Adair LS. Biological determinants of pregnancy weight gain in a Filipino population. Am.J. Clin. Nutr. 1993; 57: 365-72.

27 Wilopo S, Team CHN-RL. Key Issues on the Research Design, Data Collection and Management. Yogyakarta, Indonesia: Community Health and Nutrition Research Laboratory, Faculty of Medicine, Gadjah Mada University, 1997.

28 Nurdiati DS, Hakimi M, Wahab A, Winkvist A. Concurrent prevalence of chronic energy deficiency and obesity among women in Purworejo, Central Java, Indonesia. Food Nutr. Bull. 1998; 19: 321-33.

29 Winkvist A, Nurdiati DS, Stenlund H, Hakimi M. Predicting over- and undernutrition among women of reproductive age: a population-based study in Central Java, Indonesia. Public Health Nutr. 2000; 3: 193-200.

30 Hardiansyah, Briawan D. Penilaian dan perencanaan konsumsi pangan [Judgement and Planning for Food Composition]. Bogor, Indonesia: Jurusan gizi masyarakat dan sumber daya keluarga Fakultas Pertanian, Institut Pertanian, 1990.

31 Mahmud M, Slamet D, Apriyantono R, Hermana. Komposisi zat gizi pangan Indonesia [Composition of Indonesian Foods]. Jakarta, Indonesia: Departemen Kesehatan RI Direktorat Bina Gizi Masyarakat dan Pusat Penelitian dan Pengembangan Gizi, 1990.

32 Departemen Kesehatan RI Direktorat Jenderal Pembinaan Kesehatan Masyarakat Pusat Penelitian dan Pengembangan Gizi. Daftar komposisi zat gizi pangan Indonesia [List of Composition of Indonesian Foods]. Jakarta, Indonesia: Department of Health, 1995.

33 Schofield WN, Schofield C, James WPT. Basal metabolic rate. Hum. Nutr. Clin. Nutr. 1985; 39C(Suppl. 1): 1-96.

34 Soekirman, Tarwotjo I, Ju'sat I, Jalal F. Economic Growth, Equity and Nutritional Improvement in Indonesia. New York: United Nations, ACC/SCN, 1992.

35 Kardjati S, Kusin JA, Renqvist UH. Nutrition during pregnancy. In: Maternal and Child Nutrition in Madura, Indonesia. Amsterdam, The Netherlands: Royal Tropical Institute, 1994. 